\title{
TRAFFICKING OF SYNTHETIC OPIOIDS AND NEW PSYCHOACTIVE SUBSTANCES AS A GENERAL SECURITY RISK, AND THE INTERNATIONAL DRUG CONTROL SYSTEM
}

\author{
UDC 615.21:613.83(100) \\ 341.1
}

\author{
Igor Vukonjanski', Vladimir Kostić ${ }^{2}$ \\ ${ }^{1}$ National Academy of Public Administration, Belgrade, Serbia \\ ${ }^{2}$ Faculty of Law, Megatrend University, Belgrade, Serbia
}

\begin{abstract}
The global drug control system is enshrined in the 1961 Single Convention on Narcotic Drugs of, the 1971 Convention on Psychotropic Substances, and the 1988 United Nations Convention against Illicit Traffic in Narcotic Drugs and Psychotropic Substances. The International Narcotics Control Board, the UN body mandated to monitor the implementation of these Conventions, and the various control mechanisms prescribed by the Conventions provide a robust control system for the licit trade, production and manufacture of drugs. The development of new psychoactive substances (NPS), in particular nonscheduled synthetic opioids such as fentanyl and its analogues, pose new risks and dangers to the general public, as well as to the front-line officers most directly exposed to these substances in the drug-supply chain. In this paper, the authors present the organization and operation of the International Narcotics Control Board and the various control mechanisms prescribed by the said Conventions. As mass drug use and drug-related offenses impair the security of each country, this problem is of global importance. The aim of this paper is to present this problem, but also to show the unity of humanity in the fight against this problem. At the same time, this paper contains several recommendations that are topical for every country in the world and for the Republic of Serbia.
\end{abstract}

Key words: drug-trafficking, International Narcotics Control Board, Fentanyl, new psychoactive substances

\section{INTRODUCTION}

The international drug-trafficking landscape is changing. The diversion of drugs and chemicals from licit to illicit channels is relatively rare, due to the plethora of controls set up by three international drug conventions: the 1961 Single Convention on Narcotic Drugs,

Received May $18^{\text {th }}, 2020 /$ Accepted June $5^{\text {th }}, 2020$

Corresponding author: Igor Vukonjanski, LL.D., Associate Professor, National Academy of Public Administration, Belgrade, Serbia; e-mail: igor.vukonjanski@napa.gov.rs 
the 1971 Convention on Psychotropic Substances, and the 1988 United Nations Convention against Illicit Traffic in Narcotic Drugs and Psychotropic Substances. Today, drug traffickers are attempting to circumvent the international drug schedules by changing the chemical formulas of controlled drugs sufficiently that they become technically non controlled drugs, as they are not listed under any of the schedules. As soon as a new drug is placed under the schedules, drug traffickers already have a new chemical to produce and sell. When it comes to fentanyl, Armenian, Vo, Barr-Walker, and Lynch note: "As soon as they are regulated, new synthetic opioids appear, making detection difficult and number of cases underreported."(Aermenian, Vo, Barr-Walker \& Lynch, 2018: 121).

The U.S. Bureau of International Narcotics and Law Enforcement Affairs noted that "the harms from drug abuse, drug trafficking and related violence do not stop at national borders. The balanced approach focuses on public health, particularly the need to utilize advances in the prevention and treatment of drug abuse, as well as on reforming criminal justice policies to reflect today's challenges." Moreover, as drug-related issues call for joint action, "shared global solutions plays a key role in implementing the combat strategy. Previous distinctions between "producer" and "consumer" countries are falling away. Today, all countries must view drug policy from the perspectives of both public health and public safety. This requires a modern, evidence-based response."1

These substances are known as new psychoactive substances (NPS) and represent a real threat to public health and security. Additionally, drug trafficking modus operandi is shifting from bulk transport of drugs in containers (which is the case with cocaine) to small shipments through the postal and express courier system. Since these NPS are not controlled internationally, or even nationally at times, they are openly sold on the clear web and are extremely easy to buy. Drug traffickers send these shipments directly to the consumers through the postal system. This represents a challenge for law enforcement, as screening millions of small parcels is practically impossible. Additionally, some of these substances, such as fentanyl and its analogues, pose a real threat and danger to frontline officers in direct contact with them, as well as to the general public.

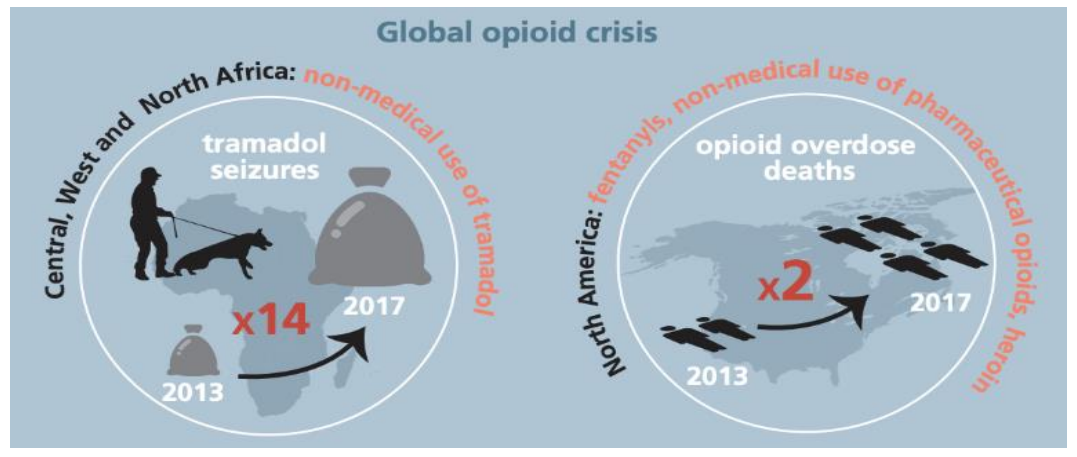

Fig. 1 Global opioid crisis (2003-2017)

Source: UNODC World Drug Report $2019^{2}$

\footnotetext{
${ }^{1}$ US Department of State, Bureau of International Narcotics and Law Enforcement Affairs, Addressing Illicit Drug Challenges, https://www.state.gov/addressing-illicit-drug-challenges/(undated); accessed 20 January 2020 ${ }^{2}$ UNODC World Drug Report 2019, Pre-release to Member States, Vienna, 19 June 2019, Powerpoint Presentation; https://wdr.unodc.org/wdr2019/prelaunch/pre-launchpresentation_WDR_2019.pdf
} 


\section{SYNTHETIC OPIOIDS}

The complexity of the world drug situation rises with the recent explosion of synthetic opioids and new psychoactive substances on the market, particularly fentanyl-related ${ }^{3}$ substances. According to the definition of the US Centres for Disease Control and Prevention (CDC), fentanyl is a synthetic opioid pain reliever, approved for treating severe pain, typically advanced cancer pain. It is 50 to 100 times more potent than morphine ${ }^{4}$.

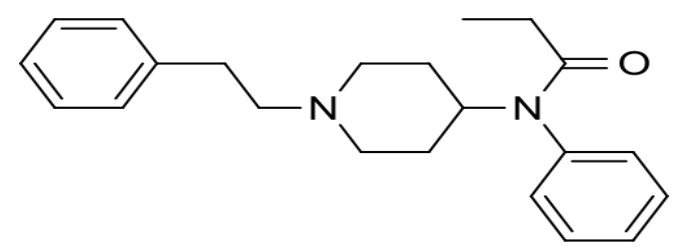

Figure 2 Chemical structure of fentanyl

According to recent data from the CDC, approximately 64,000 people died due to overdose deaths in the United States in $2016^{5}$, most of the deaths being caused by synthetic opioids, primarily fentanyl and fentanyl related substances.

One of the main reasons why fentanyl is so deadly is that drug traffickers mix it with heroin to increase its potency, and thus increase their profit margins. According to the American Addiction Centers, fentanyl is cheaper and easier to obtain than heroin ${ }^{6}$. In the process of cutting heroin with fentanyl, the drug traffickers create doses of heroin with varying amounts of fentanyl. Some doses contain almost no fentanyl, while other contain a deadly amount. Users, who are frequently unaware what they are actually buying, take their normal amount of heroin and inject a lethal amount of fentanyl in their bodies. Only $2 \mathrm{mg}$ of fentanyl can be deadly for an average adult male.

The threats of synthetic opioids, such as fentanyl, are compounded due to the modus operandi of drug traffickers. Fentanyl is being bought and sold on the surface and dark web, using untraceable crypto currencies, and delivered unknowingly by postal services. Online drug markets have a review system, similar to Amazon or e-bay, where buyers leave reviews for different products and sellers. Good reviews are directly associated when the products arrive as expected, both in quality and speed. Sellers who do not properly conceal their products when sending them through the postal system receive poorer reviews. Martin finds that the "free-market mechanism ensures that more competent sellers are rewarded with increased business, and that successful concealment techniques proliferate as a result." (Martin, 2013: 358). Vendors of drugs on these platforms replicate their advertisements on a plethora of platforms, such as social media, business-to-consumer (b2c), business-tobusiness (b2b), and the dark-net. The research done by Broséus, Rhumorbarbe, Mireault,

\footnotetext{
3 "Fentanyl is a powerful synthetic opioid that is similar to morphine but it is 50 to 100 times more potent. It is a prescription drug that is made and used illegally. Like morphine, it is a medicine that is typically used to treat patients with severe pain, especially after surgery". National Institute on Drug Abuse: Drug Facts: What is fentanyl? (February 2019); https://www.drugabuse.gov/publications/drugfacts/fentanyl

${ }^{4}$ Centers for Disease Control and Prevention, https://www.cdc.gov/drugoverdose/opioids/fentanyl.html

${ }^{5}$ Centers for Disease Control and Prevention: Provisional Drug Overdose Death Counts (March 2019), https://www.cdc.gov/nchs/nvss/vsrr/drug-overdose-data.htm

${ }^{6}$ American Addiction Centers: Fentanyl vs. Heroin: The Similarities and Differences Between Two Powerful Opioids (Nov.2019), https://americanaddictioncenters.org/fentanyl-treatment/similarities
} 
Ouellette, Crispino and Décary-Hétu shows that vendors are active on multiple platforms using similar usernames (Broséus, Rhumorbarbe, Mireault, Ouellette, Crispino,DécaryHétu, 2016: 7).

Due to fentanyl's potency at low amounts, it is very profitable for drug traffickers to ship small amounts of fentanyl in letters and small parcels. This new drug trafficking modus operandi does not only pose a challenge to law enforcement agencies, which are unable to screen millions of shipments going through the postal system, but also a serious safety risk to frontline officers, such as postal and customs officers.

According to the UNODC World Drug Report 2019, one of the key indicators adopted by the UNODC to measure the extent of drug use at the global level is the annual prevalence rate, which measures the number of people who have consumed an illicit drug at least once in the twelve-month period prior to the study. This most widely used indicator is also part of the Lisbon Consensus on core epidemiological indicators of drug use which has been endorsed by the Commission on Narcotic Drugs. The key epidemiological indicators of drug use are:

1. Drug consumption among the general population (prevalence and incidence);

2. Drug consumption among the youth population (prevalence and incidence);

3. High-risk drug use (number of injecting drug users and the proportion engaged in high-risk behaviour, number of daily drug users);

4. Utilization of services for drug problems (treatment demand);

5. Drug-related morbidity (prevalence of HIV, hepatitis B virus and hepatitis $\mathrm{C}$ virus among drug users);

6. Drug-related mortality (deaths attributable to drug use) (UNODC Report, 2019: 7). ${ }^{7}$

In 2016, the UN General Assembly held a Special Session on the World Drug Problem (UNGASS 2016), which resulted in publishing an outcome document and adopting Resolution (A/RES/S-30/1). ${ }^{8}$ In line with the commitment to effectively address, prevent and counter the illicit cultivation, production, manufacturing, trafficking and abuse of narcotic drugs, psychotropic substances and chemical opiates, the following measures should be implemented (UNGASS Resolution, 2016: 15-17):

1. Encourage awareness raising campaigns about the possible adverse risks and effects of NPS, ATS, including methamphetamine, precursors and pre-precursors, on health and safety;

2. Enhance the capacity of law enforcement agencies for detection and identification of ATS, including methamphetamine, NPS and precursors, and promote cross-border cooperation to prevent their abuse and diversion, including through the use of existing INCB and UNODC projects;

3. Continue to develop tailored prevention and treatment models and policies as well as measures aimed at reducing the supply of and demand for ATS, including methamphetamine, NPS, precursors and pre-precursors, in a comprehensive and balanced manner, including measures aimed to prevent and minimize the harm caused to individuals, families, communities and societies as a whole, and actively share information and expertise on national health-related experiences including for use at emergency stations in hospitals;

\footnotetext{
${ }^{7}$ United Nations Office on Drugs and Crime (UNODC) World Drug Report 2019, Methodology Report Research and Trend Analysis Branch, Vienna, 2019;

${ }^{8}$ UNGASS 2016: Outcome Document of the 2016 UN General Assembly Special Session on the World Drug Problem, New York, 19-21 April 2016: United Nations Office on Drugs and Crime (UNODC), Vienna; Resolution A/RES/S-30/1, adopted by the UN General Assembly in Special Session on the World Drug Problem, NY,19 April 2016.
} 
4. Consider partnerships with chemical and pharmaceutical industries as well as other relevant private sector entities, and encourage the use of the INCB Guidelines for a Voluntary Code of Practice for the Chemical Industry and a model Memorandum of Understanding between governments and private sector partners, as and where appropriate;

5. Strengthen national responses to the public health and safety threats resulting from the emergence of NPS, while ensuring their availability for legitimate purposes, including by continuing to identify and monitor trends in their composition, production, prevalence and sales, as well as patterns of use and adverse consequences within national borders, and take measures to reduce NPS demand and supply;

6. Commit to implement time-effective control or regulatory measures within national legislative and administrative systems to tackle and manage the emergence of NPS, and consider the use of interim steps while substances are under review to take temporary measures or make public health announcements as well as share information and expertise on these measures;

7. Share relevant information with, as appropriate, and strengthen the capacity of WHO, UNODC, INCB and other relevant international and regional organizations, to prioritize the review of the most prevalent, persistent and harmful NPS and to facilitate informed scheduling decisions by the CND;

8. Endorse and expand support for early warning networks and surveillance lists, increased voluntary controls and the sharing of information through the INCB, UNODC and WHO, and enhance international cooperation in the identification and reporting of NPS and incidents involving such substances and, to this end, strengthen the use of national and international established reporting systems, such as the UNODC Early Warning Advisory and Global SMART Programme;

9. Enhance the capacity and cooperation among national laboratories for detection and identification of NPS, including through the use of existing UNODC reference standards and assistance activities;

10. Endeavour to assess both, the risks to public health and safety and the actual or potential uses of NPS for medical and scientific purposes; ATS, including methamphetamine;

11. Support existing research, data collection and analysis of scientific evidence on ATS through UNODC's Global SMART Programme, strengthen international and regional cooperation in tackling ATS, including methamphetamine;

12. Promote the use of existing mechanisms such as INCB project Prism and platform PICS and joint operations and continue the development and sharing of good practices among practitioners aimed at reducing supply and demand of ATS, its precursors and pre-precursors, including best practices to prevent and minimize the harm caused by ATS; Precursors and pre-precursors;

13. Take measures to ensure national monitoring of chemicals used in the illicit manufacture of drugs and take measures to more effectively prevent the diversion of those chemicals into the illicit traffic, including by using existing INCB tools, and encourage the adoption of the I2ES;

14. Take measures to target the deliberate misuse of precursors, pre-precursors and alternative precursors in the manufacture of ATS and NPS and make use of existing INCB tools, such as PEN Online, prepared by the UNGASS Board for consideration by the CND 9 PICS to that end, and take control measures and enhance voluntary efforts at national and multilateral levels; 
15. Address the spread of pre-precursors and substitute or alternative precursors for the manufacture of narcotic drugs, psychotropic substances and NPS used to replace the traditional precursors under international control;

16. Address non-medical use and misuse of pharmaceuticals; Enhance the sharing of information on the misuse of pharmaceuticals, and the quality and consistency of reported data, including through UNODC's Annual Report Questionnaire;

17. Develop and implement countermeasures and supportive public health strategies to counter the non-medical use and misuse of pharmaceuticals, while ensuring their availability for legitimate purposes, and promote cross-border cooperation to prevent and reduce their supply from illicit sources and diversion of those substances, through the use of existing UNODC and INCB projects (UNGASS 2016: 15-17):

\section{THE INTERNATIONAL DRUG CONVENTIONS}

The current global drug control system is defined by three United Nations conventions: the 1961 Single Convention on Narcotic Drugs ${ }^{9}$, the 1971 Convention on Psychotropic Substances, ${ }^{10}$ and the 1988 Convention against Illicit Traffic in Narcotic Drugs and Psychotropic Substances. ${ }^{11}$ The aim of these conventions remains unchanged since their adoption, which is to ensure the availability of drugs for scientific and medical purposes, while limiting the illicit manufacture, trade and use of drugs. The two main bodies of the UN drug control system are the International Narcotics Control Board and the Commission on Narcotic Drugs, as the central policy-making body in the UN drug control system.

The 1961 Convention consolidated the previous international drug conventions and created the current drug control system. It put in place strict control measures on the cultivation of opium poppy, coca bush, cannabis plant and their products. A total of 134 narcotic drugs ${ }^{12}$ are controlled under the 1961 Convention schedules. The aim of the 1971 Convention was to limit the diversion and abuse of psychotropic substances, such as central nervous stimulants, sedative-hypnotics and hallucinogens. Currently, 144 psychotropic substances $^{13}$ are controlled under this Convention schedules. The 1988 Convention established a framework for the international control of precursors, chemicals used in the production of drugs. It complemented the previous treaties by defining measures against drug trafficking, such as provisions against money laundering, controlled deliveries and international cooperation through extradition of drug traffickers, and transfer of proceedings.

Today, the three UN drug conventions enjoy nearly universal adherence, with only a few countries not being signatories thereto. In 2019, according to the INCB special report Progress in ensuring adequate access to internationally controlled substances, the 1961 Convention was ratified by 187 states and the 1971 Convention was ratified by 184 states. $^{14}$

Since 1997, the UNODC has been publishing periodical estimates on the extent of illicit drug use worldwide, assessing the prevalence rates of different substances and the number of drug users. It is a difficult tasks because it involves measuring the size of a 'hidden'

\footnotetext{
${ }^{9}$ UN Single Convention on Narcotic Drugs, 1961; https://www.unodc.org/pdf/convention_1961_en.pdf

${ }^{10}$ UN Convention on Psychotropic Substances, 1971; https://www.unodc.org/pdf/convention_1971_en.pdf

${ }^{11}$ UN Convention against Illicit Traffic in Narcotic Drugs and Psychotropic Substances, 1988;

${ }^{12}$ See: International Narcotics Control Board (INCB), Yellow List, 2019

${ }^{13}$ See: INCB, Green List, 2019

${ }^{14}$ INCB:Progress in ensuring adequate access to internationally controlled substances, E/INCB/2018/Supp.1, 2019;
} 
population. Regional and global estimates are reported with ranges to reflect the information gaps. The level of confidence expressed in the estimates varies across regions and drug types.

According to the UNODC World Drug Report 2019, "a global estimate of the level of use of a specific drug involves the following steps:

1. Identification and analysis of appropriate sources (starting from the ARQ);

2. Identification of key benchmark figures for the level of drug use in all countries where data are available (annual prevalence of drug use among the general population aged 15-64) which then serve as 'anchor points' for subsequent calculations;

3. 'Standardization' of existing data if reported with a different reference population than the one used for the World Drug Report (e.g, from age group 12 and above to a standard age group of 15-64);

4. Adjustments of national indicators to estimate an annual prevalence rate if such a rate is not available (e.g., by using the lifetime prevalence or current use rates; or lifetime or annual prevalence rates among the youth population). This includes the identification of adjustment factors based on information from countries in the region with similar cultural, social and economic situations where applicable;

5. Imputation for countries where data are not available, based on data from countries in the same subregion. Ranges are calculated by considering the 10th and 90th weighted percentile of the subregional distribution, using the target population in the countries as weights;

6. Extrapolation of available results for a subregion were calculated only for subregions where prevalence estimates for at least two countries covering at least $20 \%$ of the population were available. If, due to a lack of data, subregional estimates were not extrapolated, a regional calculation was extrapolated based on the 10th and 90th percentile of the distribution of the data available from countries in the region. Since the World Drug Report 2018, when the methodology was revised, a weighted percentile procedure has been used that takes into account the population aged 15-64;

7. Aggregation of subregional estimates rolled-up into regional results to arrive at global estimates" (UNODC World Drug Report, 2019: 4).

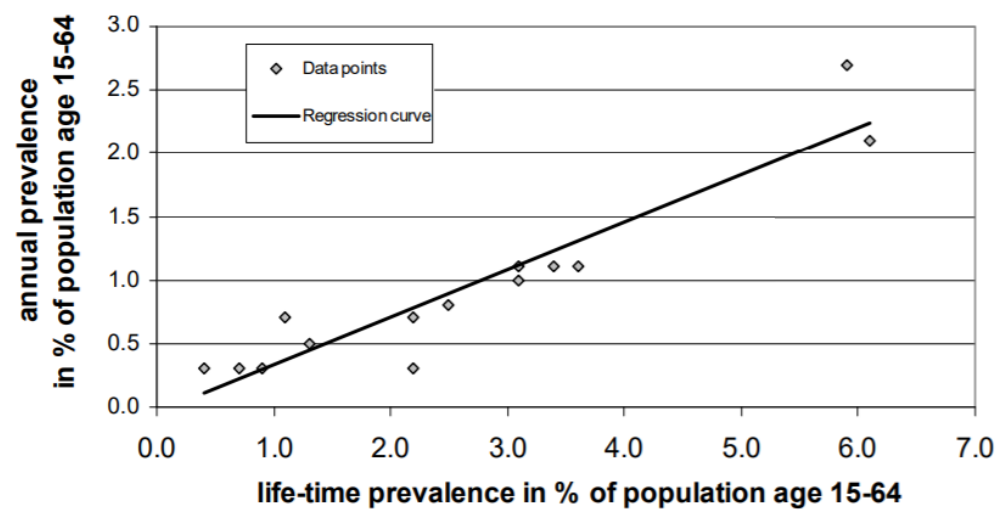

Figure 3 Example of annual and lifetime prevalence rates of cocaine use in Western and Central Europe

(Based on UNODC, Annual Reports Questionnaire Data/ EMCDDA, Annual Report) Source: UNODC World Drug Report 2019 (p.10) 
Under the International Drug Conventions, Member States are formally required to provide national drug-control-related information to the UN 'Secretary General' (i.e. the Secretariat in the UNODC) on the annuall basis. For this purpose, in 2010, the Commission on Narcotic Drugs endorsed the revised Annual Reports Questionnaire (ARQ), which is sent to Member States each calendar year for submission of responses and information on the drug-related situation. Yet, due to the information gaps and the different qualtity of the available data, States encounter ample challenges in producing such estimates. The UNODC World Drug Report 2019 idenifies some of the major problems:"One major problem is the heterogeneity in the completeness and the time frame of data coverage in ARQs reported by Member States. Irregular reporting may result in absence of data for some years and may also influence the reported trend in a given year. In addition, submitted questionnaires are not always comprehensive, and much of the data collected are subject to limitations and biases. These issues affect the reliability, quality and comparability of the information received." (UNODC World Drug Report, 2019: 1).

On the whole, practice shows that Member States lack the monitoring systems necessary to produce reliable, comprehensive and internationally comparable data. In that context, the UNODC encourages and supports the development and improvement of national monitoring systems. Over the last few years, major progress has been made in the field of monitoring illicit crop cultivation and developing monitoring systems aimed at identifying the trends and the scope of cultivation of narcotic plants in the countries that are involved in such cultivation (UNODC World Drug Report, 2019: 3).

\section{LICIT AND ILLICIT DRUG TRADE}

According to the three International Drug Conventions, all production and trade in narcotic drugs must be licensed and supervised. All Governments, both those that are signatories to the 1961 Convention and those that are not, are required to provide estimates of annual medical and scientific requirements for narcotic drugs. Maximum quantities of drugs that a Government can import are determined on the basis of these estimates, which have alegal value. Article 31 of the 1961 Convention, prohibits Governments from exporting drugs to a country or territory if the cumulative amount of narcotic drugs imported exceeds the total amount of estimates. The 1961 Convention also requires Governments to issue export and import authorizations for narcotic drugs.

Similarly, the 1971 Convention creates control mechanisms for the international trade of psychotropic substances. For example, Article 12 paragraph 1 (a) states that "Every Party permitting the export or import of substances in Schedule I or II shall require a separate import or export authorization, on a form to be established by the Commission, to be obtained for each such export or import whether it consists of one or more substances." 15

The 1988 Convention does not impose similar restrictions on import and export but, under Article 12 paragraph 10 (a), it requests from Governments to issue pre-export notifications of precursor chemicals. ${ }^{16}$

These control mechanisms make the licit international trade of drugs robust, the cornerstone of which are the estimates systems, import and export authorization and preexport notifications. Illicit drug trafficking is a much more complex and ever-changing

\footnotetext{
${ }^{15}$ UN Convention on Psychotropic Substances, Vienna, 1971.

${ }^{16}$ UN Convention against Illicit Traffic in Narcotic Drugs and Psychotropic Substances, Vienna, 1988.
} 
problem. Traditional drugs, such as cocaine and heroin, continue to pose a threat to public health and security. According to the UNODC World Drug Report 2019, estimated illicit manufacture of cocaine in 2017 reached a record high of 1,976 tons in its $100 \%$ pure form (UNODC World Drug Report, 2019: 44), while the global opium production amounted to 10,415 tons in the same year (UNODC World Drug Report, 2019: 33), which is the the highest value on record since UNODC started its annual monitoring.

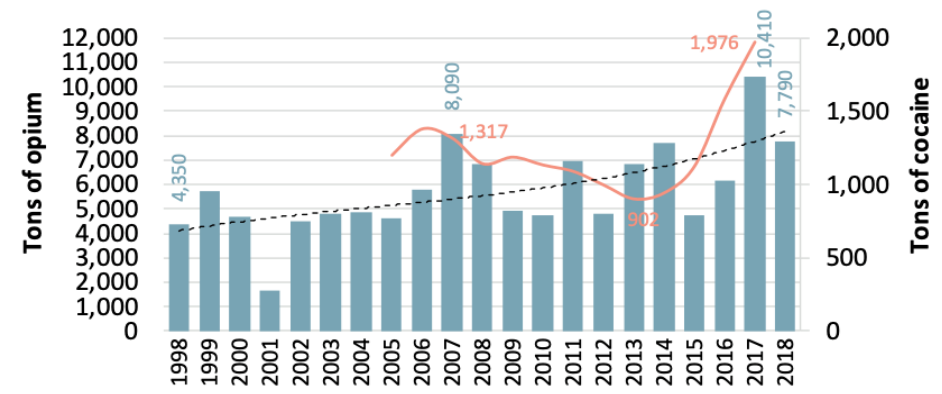

Figure 4 Global opium production and cocaine manufacture (1998-2018) Source: UNODC World Drug Report $2019^{17}$

The analysis presented in this paper is mainly derived from the ARQ responses submitted by the Member States up to the 2017 reporting year. Including information from other sources, the UNODC was able to obtain seizure data from 123 countries and territories for the year 2017. Over the 2013-2017 period, seizure data were obtained from a total of 156 countries and territories. Seizures are thus the most comprehensive indicator of the drug situation and its evolution at the global level. ${ }^{18}$ On the other hand, as shown in the below chart, record high seizures of cocaine curb the supply side.

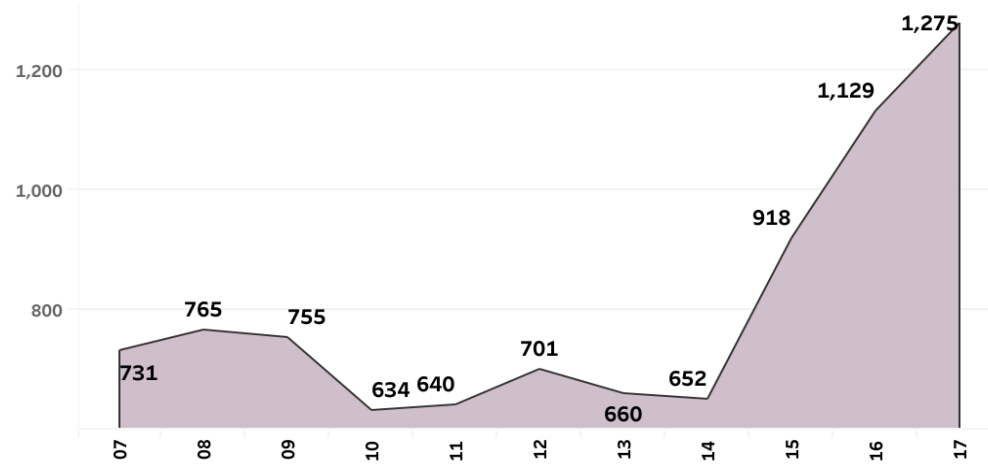

Figure 5 Global seizures of Cocaine (2007 - 2017)

Source: UNODC World Drug Report 2019, all figures shown are in metric tons. ${ }^{19}$

\footnotetext{
${ }^{17}$ UNODC World Drug Report 2019 (Powerpoint presentation): https://wdr.unodc.org/wdr2019/prelaunch/prelaunchpresentation_WDR_2019.pdf

${ }^{18}$ The UNODC continues to record and report the disaggregated raw data, which are available in the seizure listings published at: http://www.unodc.org/unodc/en/data-and-analysis/WDR.html

${ }^{19}$ UNODC World Drug Report 2019 (online): https://wdr.unodc.org/wdr2019/
} 
According to the UNODC World Drug Report 2019, “one key problem in national data is the level of accuracy, which varies strongly from country to country. Not all estimates are based on sound epidemiological surveys. In some cases, the estimates simply reflect the aggregate number of drug users found in drug registries, which cover only a fraction of the total drug using population in a country. Even in cases where detailed information is available, there is often considerable divergence in definitions used, such as chronic or regular users; registry data (people in contact with the treatment system or the judicial system) versus survey data (usually extrapolation of results obtained through interviews of a selected sample); general population versus specific surveys of groups in terms of age (such as school surveys), special settings (such as hospitals or prisons), or high risk groups, etc.” (UNODC Report, 2019: 6).

\section{THE INTERNATIONAL NARCOTICS CONTROL BOARD}

\subsection{Foundation of the International Narcotics Control Board}

The International Narcotics Control Board (INCB) was established under the 1961 Convention on Narcotic Drugs as an independent, quasi-judicial expert body in charge of monitoring the implementation of the three UN drug control conventions. The Board was founded by combining two different bodies: the Permanent Central Narcotics Board, established by the 1925 International Opium Convention, and the Drug Supervisory Body, established by the 1931 Convention for Limiting the Manufacture and Regulating the Distribution of Narcotic Drugs. The Board is the oldest drug-control body which, with its predecessor organisations, predates even the establishment of the United Nations. ${ }^{20}$

The Board has a dual mandate. As for licit drugs, the Board monitors the Governments' control over chemicals used in the licit manufacture of drugs, advises Governments on preventing the diversion of those chemicals into the illicit traffic, and ensures that adequate supplies of drugs are available for scientific and medical uses. As for the illicit manufacture of, trafficking in and use of drugs, the Board identifies weaknesses in national and international drug control systems and contributes to fixing the observed problems. The Board is also responsible for assessing various chemicals used in the illicit manufacture of drugs to determine whether they should be placed under international control. ${ }^{21}$

\subsection{Organisational Structure}

The International Narcotics Control Board (INCB) consists of 13 members, each elected by the UN Economic and Social Council (ECOSOC) for a period of five years. Three of the members must be nominated by the World Health Organization (WHO). The Board elects its own president for a term of one year. Once elected, the Board members serve the INCB impartially and independently of their Governments.

The Board also has a Secretariat, which is administratively part of the United Nations Office on Drug and Crime (UNODC) but, according to the 1991 Administrative Arrangements to ensure full technical independence of the Board ${ }^{22}$, it is under the full

\footnotetext{
${ }^{20}$ The International Narcotics Control Board (INCB) website: https://www.incb.org/incb/en/about.html

${ }^{21}$ INCB website: https://www.incb.org/incb/en/about/mandate-functions.html

${ }^{22}$ ECOSOC Resolution E/RES/1991/48 - Administrative arrangements to ensure the full technical independence of the International Narcotics Control Board, economic and Social Council, 1991;
} 
direction of the Board in all substantive matters. The Secretariat is in charge of implementing the treaty-mandated functions of the Board and its decisions ${ }^{23}$.

\subsection{The Role of the International Narcotics Control Board}

In accordance with the international drug conventions, the Board has the following duties:

1. to administer a system of estimates for narcotic drugs, as well as a voluntary assessment system for psychotropic substances, and monitor licit activities involving drugs through a statistical returns system, with a view to assisting Governments in achieving, inter alia, a balance between supply and demand;

2. to monitor measures taken by Member States to prevent the diversion of substances used in illicit manufacture of narcotic drugs and psychotropics substances, and to assess these substances to determine whether they should be placed under international control;

3. to analyze information provided by various parties, such as Member States, UN bodies or other international organizations to ensure that the international drug control conventions are implemented by Member States, and if necessary, recommend remedial measures;

4. to maintain a permanent dialogue with Governments to support them in implementing the international drug control conventions and, if necessary, recommend technical or financial assistance to be provided. $^{24}$

\subsection{Reports of the Board}

The Board publishes an annual report, which provides a comprehensive survey of the drug control situation in various parts of the world. The report is supplemented by technical reports on the prevalence rates of narcotic drugs and psychotropic substances, detailed account of estimates in each country, as well as data on the licit production, manufacture, trade and consumption of these drugs worldwide. As an impartial body, the Board tries to identify and predict trends and recommend necessary measures that have to be taken. The report is submitted to the ECOSOC through the Commission on Narcotic Drugs. The Board also reports to the Commission on the implementation of Article 12 of the 1988 Convention against Illicit Traffic in Narcotic Drugs and Psychotropic Substances, by providing analysis on the trends in illicit trafficking in such substances and the measures Governments have taken against the diversion of precursors and essential chemicals. ${ }^{25}$

\section{PROJECTS OF THE INTERNATIONAL NARCOTICS CONTROL BOARD}

As a result of numerous resolutions adopted by the General Assembly, the Economic and Social Council, and the Commission on Narcotic Drugs, calling the Board to suppoert Governments in their efforts to prevent dangerous substances from reaching consumer markets, the Board initiated multiple global projects, such as: Projects Prism and Cohesion, Project ION (International Operations on New Psychoactive Substances), and the OPIOIDS (Operational Partnerships to Interdict Opioids Illicit Distribution and Sales), which were aimed at implementing the recommendations stipulated in the UNGASS 2016 document.

\footnotetext{
${ }^{23}$ The INCB Secretariat: https://www.incb.org/incb/en/about/secretariat.html;

${ }^{24}$ INCB website: https://www.incb.org/incb/en/about/mandate-functions.html

${ }^{25}$ INCB website: https://www.incb.org/incb/en/about/mandate-functions.html
} 


\subsection{Projects Prism and Cohesion}

Project Cohesion (since 2006) and Project Prism (since 2003) serve as the basis of the INCB's work on international cooperation, aimed at supporting Governments to prevent trafficking in chemicals frequently used in manufacturing drugs. Project Cohesion focuses on the precursors of cocaine and heroin, while Project Prism focuses on amphetamine-type stimulants and other synthetic drugs ${ }^{26}$.

\subsection{Project ION}

Project ION is the INCB international project aimed at supporting Governments to prevent non-controlled new psychoactive substances (NPS) from reaching consumer markets. The project focuses on synthetic new psychoactive substances that have almost no known medical, scientific or industrial uses. Project activities primarily involve the coordination, collection and communication of strategic and operational information and intelligence related to suspicious manufacture or production, shipments of or trafficking in NPS. As noted on the project website, "Project ION establishes and maintains a mechanism for multilateral operational activities; enables and supports intelligence generation and dissemination (e.g. Special Alerts) to national focal points, raises awareness about the threat of and practical response to NPS, strengthens international partnerships and cooperation, and provides access to the IONICS secure communication platform for the real-time sharing of actionable intelligence on incidents involving NPS between Governments." 27

\subsection{OPIOIDS Project}

The goal of the OPIOIDS Project is to support Governments and international organizations in preventing non-medical synthetic opioids and fentanyl-related substances from reaching consumer markets; it is to be achieved by:

1. developing international agency and industry partnerships with those who have a practical role to play in responding to the crisis;

2. increasing awareness regarding the nature and scale of synthetic opioids and fentanylrelated substances problem;

3. supporting international initiatives that enhance information-sharing and facilitate cooperation for detection and communication of trafficking;

4. promoting technical assistance and training programmes that ensure safety and security $^{28}$.

\section{CONCLUSION}

To effectively combat the growing threat of synthetic opioids and other new psychoactive substances, innovative approaches have to be implemented. The Board's operational projects support Governments in responding to these challenges by supporting multilateral cooperation, intelligence gathering and analysis, which is crucial in addressing the ever-changing drug problem. Considering the general exponential growth of online e-

\footnotetext{
${ }^{26}$ INCB website: https://www.incb.org/incb/en/precursors/special_projects/Prism_and_Cohesion.html

${ }^{27}$ INCB website: https://www.incb.org/incb/en/project_ion.html

${ }^{28}$ INCB website: https://www.incb.org/incb/en/opioids_project.html
} 
commerce and people turning to the Internet to purchase drugs, websites both on the surface and dark web are rapidly coming to the fore. The risks and dangers posed by these sites, and the ease by which drugs are bought and shipped, represent a real threat. New tools are available, such as "advanced electronic data" (AED), which provide the United State Postal Inspection Services and Customs and Border Protection with information about the contents of international packages before they reach the United States. In order to prevent the illicit drug importation, the US has already imposed specific requirements on international packages coming into the country through private carriers like FedEx and UPS, but they will start applying to international packages arriving through USPS in $2021^{29}$.

Other Governments applying the same procedures might help curb the amount of drugs being shipped through the postal system. The Board and its Secretariat are in a unique position to collect and exchange intelligence with Governments, supporting them in detecting suspicious shipments of new psychoactive substances, especially fentanyl. Going forward, multilateral cooperation will be key in ensuring a successful response to a serious and ever-changing threat of new psychoactive substances. It entails a number of preventive measures:

1. take effective and practical measures to protect and prevent human beings, in particular children and young people from the illicit use of narcotic drugs and psychotropic substances by promoting opportunities to develop healthy lifestyles, life skills, supportive parenting and family environments, as well as by ensuring equal access to all levels of education and vocational training;

2. increase the availability, coverage and quality of scientific evidence-based measures and instruments that target relevant age and risk groups, youth at school and out of school, by using, among others, social media and online platforms to prevent and reduce drug initiation and prevent transition to drug use disorders;

3. involve researchers, policy makers and educators, civil society and the private sector in the development of awareness raising programmes, public prevention campaigns, health and education program, and involve parents, teachers, students, health professionals, the religious community, community leaders, social workers, and media professionals in their implementation (as appropriate);

4. develop appropriate prevention curricula for use at all levels of the education system, and enhance the capacity of teachers, care providers and community institutions to provide counselling and prevention services for children and young people;

5. develop and improving recreational facilities, guaranteeing access for children and youth, and arrange regular sports and cultural activities to promote healthy lifestyles;

6. promote and improve systematic collection of information and sharing of reliable and comparable data on drug use and prevalence, and promote the use of internationally recognized standards, such as the International Standards on Drug Use Prevention, to formulate effective prevention strategies and programmes in coordination with competent actors, such as the UNODC and the WHO (UNGASS 2016: 5-6).

On the other hand, there are highly important measures which have to be taken for the purpose of preventing drug-related crime:

1. strengthen multidisciplinary efforts at international, regional, national and local and community levels in preventing drug-related crime and violence, and integrate such measures within overall law enforcement efforts;

\footnotetext{
${ }^{29}$ US Congress: Public Law No.115-271 (10/24/2018)
} 
2. promote data collection, research and sharing of information as well as exchange of best practices, and encourage the launching of pilot programmes and research initiatives on prevention and countering of drug-related crime as well as on drug supply reduction measures and practices, in order to accelerate criminal justice reforms within the framework of the international drug control conventions;

3. promote a culture of lawfulness that supports the rule of law and observance of human rights while respecting cultural identities by developing and implementing, as appropriate, comprehensive policies and programmes aimed at addressing the multidimensional factors that contribute to drug-related crime, violence and victimization, fostering social development and inclusiveness. (UNGASS 2016: 10-11).

Another important set of measures refers to countering international drug production and illicit trafficking in narcotics and psychotropic substances, including their eradication:

1. strenghten and increase cooperation at all levels with a view to effectively reduce or eliminate the illicit cultivation of opium poppy, coca bush and cannabis plant used for the production of narcotic drugs, within the framework of sustainable crop control measures;

2. monitor current trends and trafficking routes and share experiences in order to prevent the abuse of legitimate commercial trade (including the use of land, maritime and aerial routes) for illicit activities, and enhance the existing UNODC operational initiatives including the Containers Control Programme and AIRCOP, as well as other technical assistance activities to achieve these objectives;

3. promote and strengthen exchange of intelligence and information, as appropriate, among law enforcement and border control agencies, including through the UNODC multilateral portals, regional information centres and networks, and promote jointly coordinated operations, bilaterally, subregionally, regionally and internationally and the development of joint training platforms to facilitate such coordinated operations in order to identify, disrupt and dismantle transnational organized criminal groups involved in any illicit activities related to the illicit production and trafficking of narcotic drugs and psychotropic substances;

4. strengthen coordinated border management strategies as well as the capacity of border control and law enforcement agencies, through technical assistance, upon request, including the provision of equipment and technology along with necessary training and maintenance support, in order to prevent, monitor and counter drug trafficking, trafficking in precursors and other related illicit activities, such as trafficking in firearms and smuggling of bulk cash;

5. enhance the capacity of law enforcement and criminal justice agencies in forensic science in the context of drug investigation activities aimed at gathering, preserving and presenting forensic evidence to effectively prosecute trafficking offences, inter alia, through the provision of advanced detections equipment, scanners, testing kits, forensic laboratories and training;

6. strengthen regional, sub-regional and international cooperation in criminal matters, as appropriate, including judicial cooperation, inter alia, in the areas of extradition, mutual legal assistance and transfer of proceedings in accordance with the international drug control conventions, and strive to appropriately resource national competent authorities including through the provision of targeted technical assistance to requesting countries;

7. encourage that supply reduction efforts should primarily focus on individuals and organizations with a significant or controlling role in drug trafficking activities. (UNGASS 2016: 10-12). 


\section{REFERENCES}

Armenian, P., Vo, K. T., Barr-Walker, J., \& Lynch, K. L. (2018). Fentanyl, fentanyl analogs and novel synthetic opioids: A comprehensive review. Neuropharmacology, 134, 121-132. doi:10.1016/j.neuropharm.2017.10.016

American Addiction Centers: Fentanyl vs. Heroin: Similarities and Differences. (Nov.2019), https://americanaddictioncenters.org/fentanyl-treatment/similarities

Broséus, J., Rhumorbarbe, D., Mireault, C., Ouellette, V., Crispino, F., \& Décary-Hétu, D. (2016). Studying illicit drug trafficking on Darknet markets: Structure and organisation from a Canadian perspective. Forensic Science International, 264, 7-14. doi:10.1016/j.forsciint.2016.02.045

Martin, J. (2013). Lost on the Silk Road: Online drug distribution and the "cryptomarket." Criminology \& Criminal Justice, 14(3), 351-367. doi:10.1177/1748895813505234

Centers for Disease Control and Prevention: Provisional Drug Overdose Death Counts (March 2019), https://www.cdc.gov/nchs/nvss/vsrr/drug-overdose-data.htm; https:/www.cdc.gov/drugoverdose/opioids/ fentanyl.html

International Narcotics Control Board (INCB) website: https://www.incb.org/incb/en/about.html; https://www.incb. org/incb/en/about/secretariat.html; https://www.incb.org/incb/en/about/mandate-functions.html;

International Narcotics Control Board, Yellow List, 2019; https://www.incb.org/documents/Narcotic-Drugs/ Yellow_List/58th_Edition/Yellow_List_-ENG.pdf

International Narcotics Control Board, Green List, 2019; https://www.incb.org/documents/Psychotropics/ forms/greenlist/Green_list_ENG_08673.pdf

International Narcotics Control Board (INCB): Projects Prism and Cohesion;, https://www.incb.org/incb/en/ precursors/special_projects/Prism and Cohesion.html

International Narcotics Control Board: https://www.incb.org/incb/en/project_ion.html

International Narcotics Control Board: https://www.incb.org/incb/en/opioids_project.html

International Narcotics Control Board: Progress in ensuring adequate access to internationally controlled substances, E/INCB/2018/Supp.1, Vienna, 2019; https://www.incb.org/documents/Publications/ AnnualReports/AR2018/Supplement/Supplement_E_ebook.pdf

National Institute on Drug Abuse: Drug Facts: What is fentanyl? (February 2019); https://www.drugabuse. gov/publications/drugfacts/fentanyl

UN Single Convention on Narcotic Drugs, New York, USA, 1961; https://www.unodc.org/pdf/convention 1961_en.pdf

UN Convention on Psychotropic Substances, Vienna, Austria, 1971, https://www.unodc.org/pdf/convention 1971_en.pdf

UN Convention against Illicit Traffic in Narcotic Drugs and Psychotropic Substances, Vienna, 1988, https://www.unodc.org/pdf/convention_1988_en.pdf

UNODC United Nations Office on Drugs and Crime: UNODC World Drug Report 2019, Methodology Report Research and Trend Analysis Branch, Vienna, 2019; https://wdr.unodc.org/wdr2019/prelaunch/WDR2019-Methodology-FINAL.pdf

UNGASS 2016: Outcome Document of the 2016 UN General Assembly Special Session on the World Drug Problem, New York, 19-21 April 2016: UNODC, Vienna; https://www.unodc.org/documents/ postungass2016/outcome/V1603301-E.pdf;

UN Resolution A/RES/S-30/1, adopted by the UN General Assembly in Special Session on the World Drug Problem, New York, 19 April 2016; https://undocs.org/A/RES/S-30/1;

UN ECOSOC Resolution E/RES/1991/48-Administrative arrangements to ensure the full technical independence of the INCB, Economic and Social Council, New York, 1991, https://www.unodc. org/unodc/en/Resolutions/resolution_1991-06-21_10.html

US Congress: Public Law No: 115-271 (10/24/2018) - Substance Use-Disorder Prevention that Promotes Opioid Recovery and Treatment for Patients and Communities Act or the SUPPORT for Patients and Communities Act, H.R.6 - 115th Congress (2017-2018); https://www.congress.gov/bill/115th-congress/ house-bill/6, Journal of Democracy, Vol.3, No.9, pp. 112-126.

Прица, М. (2018). Правни принципи у поретку правне државе: канони правног поретка и „унутрашњег правног система“, Зборник радова Правног факултета у Нишу, Vol. LVII, бр. 80, pp. 135-180.

Property Rights Alliance (2018). International Property Rights Index 2018, available at https://www.internationalpropertyrightsindex.org/full-report/ 10.03.2019.

Przeworski, A. (1991). Democracy and the Market. Political and Economic Reforms in Eastern Europe and Latin America, Cambridge University Press, Cambridge.

Roessler, P.G. \& Howard, M.M. (2009). Post-Cold War Political Regimes: When Do Elections Matter?/ In Staffan I. L. (ed), Democratization by Elections: A New Mode of Transition/.- The Johns Hopkins University Press, Baltimore. 
Sagay, I. (1996). The Travails of Democracy and the Rule of Law/ In Ajomo, M.A., Sambo, A. (eds), Democracy and the Rule of Law/.- Spectrum Books Ltd, Ibadan, Nigeria.

Schumpeter, J. (1942). Capitalism, Socialism and Democracy, Harper Perennial, London.

World Bank (2017). Worldwide Governance Indicators 2017. http://info.worldbank.org/governance/wgi/\#reports/ (accessed 12.03.2019).

World Justice Project (2012). Rule of Law Index 2012. https://worldjusticeproject.org/sites/default/files/documents/ WJP_Index_Report_2012.pdf (accessed 15.03.2019).

World Justice Project (2019). Rule of Law Index 2019. https://worldjusticeproject.org/our-work/research-and-data/wjprule-law-index-2019/ (accessed 12.03.2019).

\section{TRGOVINA SINETETIČKIM OPIOIDIMA I NOVIM PSIHOAKTIVNIM SUPSTANCAMA KAO BEZBEDNOSNI RIZIK, I MEĐUNARODNI SISTEM KONTROLE NARKOTIKA}

Globalni sistem kontrole droga, osnovan Jedinstvenom konvencijom o opojnim drogama iz 1961, Konvencijom o psihotropnim supstancama iz 1971., i Konvencijom Ujedinjenih nacija protiv nezakonitog prometa opojnih droga i psihotropnih supstanci iz 1988. Telo UN-a ovlašteno da nadgleda sprovođenje Konvencija, Međunarodni odbor za kontrolu narkotika i različiti mehanizmi kontrole propisane konvencijama pružaju čvrstu kontrolu sistem za legalnu trgovinu i proizvodnju lekova. Razvojem novih psihoaktivnih supstanci (NPS), posebno sintetičkih opioida koji nisu kontrolisani pod međunarodnim konvencijama, kao što su fentanil i njegovi analozi, stvaraju se novi rizici i opasnosti za širu javnost, kao i one koji su direktno izloženi tim substancama u njihovom prometu. Autori ovog rada želeli su da predstave široj javnosti organizaciju i rad Međunarodnog odbora za kontrolu narkotika $i$ različite mehanizme kontrole propisane navedenim konvencijama.

Takođe, kako masovna upotreba droga i prestupi sa drogom narušavaju sigurnost svake zemlje, ovaj problem je od globalnog značaja. Stoga je cilj ovog rada predstaviti ovaj problem na pravi način, ali $i$ pokazati jedinstvo čovečanstva u borbi protiv ovog problema. Ovaj dokument istovremeno sadrži nekoliko preporuka koje su aktuelne za sve zemlje u svetu i za Republiku Srbiju.

Ključne reči: droga, Međunarodni odbor za kontrolu narkotika, Fentanil, nove psihoaktivne supstance 